\title{
Michael Webster
}

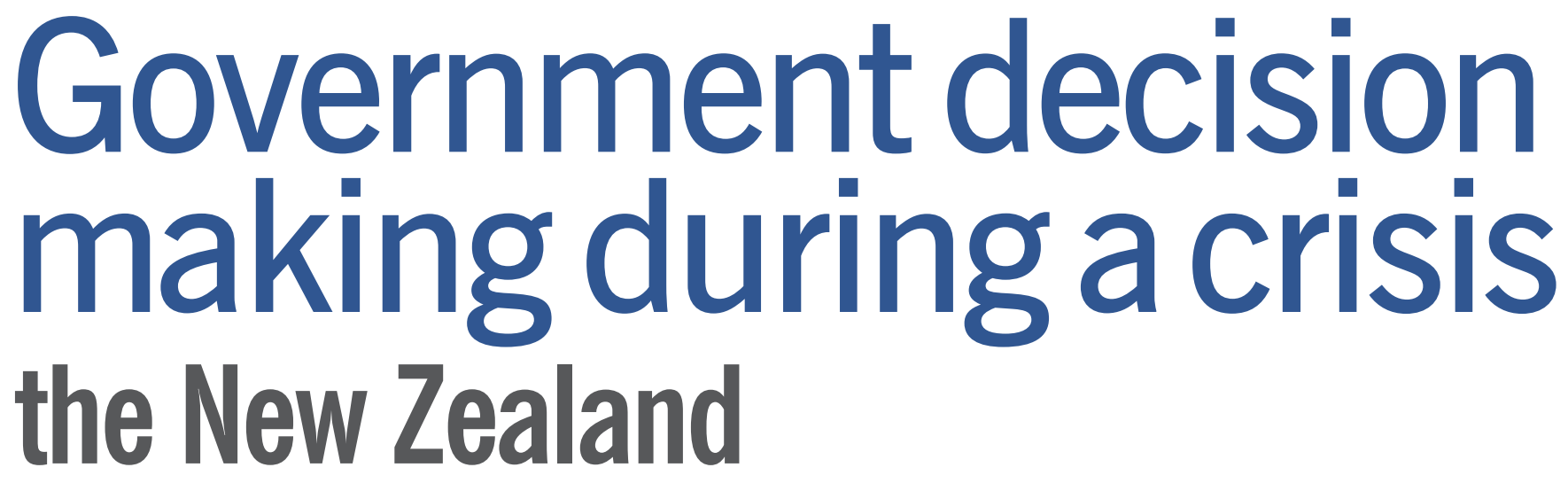

\begin{abstract}
A key component of New Zealand's response to the Covid-19 pandemic was how the government was organised and supported to make decisions in relation to the health, economic, social, foreign policy, legal and other policy issues it faced. The New Zealand system of central government decision making, as set out in the Cabinet Manual and operated by the Cabinet Office, was continually adapted to ensure that the Prime Minister and Ministers, and the officials working to them, were provided with a system that facilitated both rapid and considered decision making and promulgation of those decisions.
\end{abstract}

Keywords Covid-19, Cabinet, Prime Minister, Ministers, executive, decision making

Michael Webster is the Secretary of the Cabinet. He has previously held a range of senior roles in central and local government.

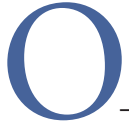

n Saturday, 1 February 2020 something out of the ordinary - at least by New Zealand government standards - happened. The Cabinet, the central decision-making body of executive government, met late at night by teleconference. At the meeting, Cabinet received an update on the novel coronavirus outbreak, including proposed enhanced border measures. Cabinet also authorised a group of Ministers to have power to act to take decisions on New Zealand's response to the outbreak and border measures. On the following Sunday, 2 February, Ministers with power to act agreed to a series of border measures. Those border measures were kept under review throughout February and into March by the group of Ministers, and Cabinet, with amendments agreed to from time to time.

At its meeting on Monday, 2 March 2020, Cabinet noted that an Ad Hoc Cabinet Committee on the Covid-19 Response (CVD) would be established. It was clear that the response to Covid-19 would continue to dominate New Zealand's 
system of central government decision making for some time to come.

New Zealand's system of central government decision making

One of the greatest strengths of $\mathrm{New}$ Zealand's democracy is its system of Cabinet government. It's a system that ensures that decisions are taken by informed Ministers working together to achieve collective goals. An understanding of how that system is structured and operates is key to understanding how the New Zealand government considered advice and made decisions in response to the Covid-19 pandemic.

The Cabinet Manual has, for many years now, been the authoritative guide to New Zealand's system of central government decision making. It sets out Cabinet's practices and procedures. Its content reflects the stable and underlying traditions and conventions of democratic government in New Zealand. The principles in the Manual represent all that is best about our system of executive government: robust decision-making processes, respect for the law, integrity, effectiveness and efficiency, openness and accountability.

There is a long-standing recognition in New Zealand that good process is a worthy goal in its own right - contributing to good policy, respect for the institutions of government and, in the end, good outcomes for the people of New Zealand.

Chapter 5 of the Cabinet Manual is concerned with Cabinet decision making. The key principles and guidance set out in this chapter that inform a consideration of the government response to the Covid-19 pandemic are:

- [Cabinet] is a collective forum for Ministers to decide significant government issues and to keep colleagues informed of matters of public interest and controversy.

- Cabinet is central to New Zealand's system of government. It is established by convention, not law. The legal powers of the Executive are exercised by those with statutory authority to act (for example, the Governor-General, the Governor-General in Council, or individual Ministers). In practice, however, all significant decisions or
The Ad Hoc Cabinet Committee on the Covid-19 Response met four times in March ... sometimes in person and sometimes by teleconference, to receive updates

\section{and discuss a range of matters, including border} measures.

actions taken by the Executive are first discussed and collectively agreed by Cabinet.

- Cabinet determines and regulates its own procedures. Final decisions on Cabinet procedures rest with the Prime Minister, as the chair of Cabinet.

- Cabinet committees provide the forum for detailed consideration and discussion of issues before their reference to Cabinet, with officials available to assist Ministers if the committee wishes.

Occasionally, Cabinet or the Prime Minister will authorise a Cabinet committee or specified Ministers (a group of Ministers) to have 'power to act' (that is, power to take a final decision) on a clearly defined item. Where a committee or specified Ministers take a decision under power to act, the decision can be acted on immediately.

- Papers are submitted to Cabinet committees and Cabinet to enable Ministers to make collective decisions based on sound information and analysis. Good papers reflect robust policy development and consultation processes, are informed by evidence and insights from diverse perspectives, and are analytically sound. They are succinct yet sufficiently comprehensive to provide Ministers with all the information they need to reach an informed decision.

- In cases of particular urgency or confidentiality, or to update Cabinet on a current issue, or to test preliminary support for a proposal, a Minister may wish to raise an oral item at a Cabinet or Cabinet committee meeting.

- The Cabinet Office supports meetings of Cabinet (in the Cabinet Room) and Cabinet committees (in the separate Cabinet committee meeting room).

- Issues are often debated vigorously in the confidential setting of Cabinet meetings, although consensus is usually reached and votes are rarely taken.

- The Cabinet Office publishes on CabNet [a secure electronic system for managing Cabinet material], and where required distributes in hard copy, minutes of Cabinet and Cabinet committee decisions as soon as possible after each meeting, recording the decisions in a form that allows the necessary action to be taken. (Cabinet Office, 2017)

\section{Government decision making during}

the pandemic: a timeline

The impact of the Covid-19 pandemic on the decision-making processes of executive government in New Zealand is perhaps best seen by setting out, in a chronological fashion, the various steps and events that happened following that first teleconference Cabinet meeting in early February 2020.

The Ad Hoc Cabinet Committee on the Covid-19 Response met four times in March (4, 11, 12 and 18 March), sometimes in person and sometimes by teleconference, to receive updates and discuss a range of matters, including border measures.

On 19 March, Cabinet authorised a group of Ministers to have power to act in relation to the government response to Covid-19, comprising the Prime Minister, Deputy Prime Minister, Hon Kelvin Davis, Hon Grant Robertson, Hon Chris Hipkins, Hon 
Carmel Sepuloni, Hon Dr David Clark and Hon James Shaw. This group, known as the Covid-19 Ministerial Group (CMG), replaced the CVD, and reinforced decision-making flexibility to respond to the urgency of the matters facing Ministers, supported by their public service advisors. Formally, its role was to coordinate and direct the government response to the Covid-19 outbreak.

The Covid-19 Ministerial Group was not a Cabinet committee. Given the group's critical role, the Cabinet Office, rather than departmental officials, provided the secretariat support to this group: receiving papers, generating its agendas, running its meetings and preparing minutes of its decisions.

At its 19 March 2020 meeting, Cabinet also agreed to close New Zealand's borders to everyone except New Zealand citizens and permanent residents (with some exceptions).

The following day, the CMG agreed to the alert level framework and agreed to move New Zealand to alert level 2 as soon as practicable.

On Monday, 23 March, Cabinet took place under physical distancing procedures. Only ten Ministers attended in person, with the rest of Cabinet joining the meeting through teleconference. It was to be the last face-to-face meeting of Cabinet until the move back to alert level 3 in late April.

At that meeting Cabinet:

- agreed to raise the alert level, beginning with a rise to alert level 3 on Monday, 23 March;

- agreed in principle to move to alert level 4 at the earliest practicable opportunity and no later than within 48 hours, for an initial four-week period (it was subsequently extended to Monday, 27 April); and

- agreed that declaring a state of emergency under the Civil Defence Emergency Management Act 2002 was the preferred approach to allow the measures in level 4 .

The CMG met again on Wednesday, 25 March 2020, and: a) confirmed the decision to move to alert level 4 at $11.59 \mathrm{pm}$ on Wednesday 25 March 2020 for an initial four week period; and b) noted that the Minister of Civil Defence would declare a state of national emergency on 25 March 2020.

The CMG, Cabinet or the Cabinet Business Committee (CBC), with some
The sheer volume of items considered by the government that were directly related to the Covid-19 pandemic, and the response and recovery, was, by
any stretch of the
imagination,
significant.

variations, met nearly every day, including weekends, during alert level 4 . The weekly cycle looked something like: Cabinet on Monday; CMG on Tuesday; CBC on Wednesday; and CMG on Thursday, Friday and also in the weekend.

A 'battle rhythm' for meetings soon emerged. Officials worked closely with the Prime Minister, Ministers and the Prime Minister's Office in scheduling and preparing papers for decision making. Those papers would be received electronically by members of the Cabinet Office team on duty (working both from home and in the Beehive) by around $4.00 \mathrm{pm}$ the day before a meeting. An agenda would be prepared, and the papers distributed to Ministers and the officials who supported them. The meetings themselves normally took place by videoconference the following day. After the meetings, the minutes would be prepared and distributed, and a handover to the next Cabinet Office team would take place, as they in turn waited for the next set of papers for the following day's meeting to be provided for distribution. It was, as all those involved would acknowledge, a relentless yet mostly smoothly functioning process.

The sheer volume of items considered by the government that were directly related to the Covid-19 pandemic, and the response and recovery, was, by any stretch of the imagination, significant. By midJune 2020, when New Zealand went back to alert level 1, the total had reached over 250. This number includes oral items as well as papers. Some of these items were considered more than once. For example, a matter might have been considered at Cabinet one week, and then an updated paper on the same matter submitted for Cabinet the following week.

During this time, a number of Orders in Council needed to be made by the Governor-General, on the advice of Ministers. In normal times, once Cabinet has approved an Order for signature, the Governor-General signs it at a meeting of the Executive Council, held in the Executive Council Meeting Room in the Beehive, with the necessary Ministers present. The lockdown meant that this standard procedure had to be adapted. Meetings of the Executive Council were held by videoconference, at the conclusion of Cabinet, $\mathrm{CBC}$ or CMG meetings, with the Prime Minister presiding. Once approved, the Orders and associated advice sheets were scanned and sent to the GovernorGeneral. They were then printed out, signed by Her Excellency, and then gazetted.

On 28 April 2020 New Zealand moved back to alert level 3. At this point, the normal cycle of Cabinet and Cabinet committee meetings resumed, with some Ministers attending in person and some attending over videoconference in order to meet public health requirements.

On 14 May 2020 New Zealand moved down to alert level 2. Meetings now took place again in the Cabinet Room. A second tier of tables was set up around the main table, allowing the full Cabinet to be present but with the appropriate distancing in place. The Cabinet Room was used for all Cabinet and Cabinet committee meetings until the move to alert level 1.

On 8 June 2020 Cabinet met to consider moving New Zealand to alert level 1. That was agreed with effect from $11.59 \mathrm{pm}$ that night.

\section{Supporting Ministers to work remotely}

In the normal course of events, papers for Cabinet and Cabinet committees are submitted through the Cabinet Office's 
CabNet system. Once those papers have been processed by the Cabinet Office, and an agenda prepared, the Cabinet Office copies and distributes hard copies to those Ministers who want them in that format. Under the higher alert levels, the Cabinet Office was unable to distribute hard copies of papers. Happily, the Cabinet Office also has an application called CabDocs, which is linked to CabNet and enables Ministers to read their Cabinet material electronically on a laptop or tablet device.

\section{Use of audiovisual technology}

Of course, during an alert level 4 lockdown you cannot hold face-to-face, or round the table, Cabinet or ministerial meetings. Early on, Ministers met by teleconference. The limitations with teleconferencing when seeking to run, take part in and support the critical decision-making meetings in those early days led to a move to running the meetings using videoconferencing.

Many of those involved in the Covid-19 response and recovery decision-making process were already familiar with videoconferencing tools. However, as with anything new and involving IT, the move to online meetings did involve, for some participants, sorting IT system compatibility issues, upskilling in this sort of meeting technology, and rapidly acquiring the skills and behaviours necessary to ensure an effective discussion and decision-making experience. The subsequent move, under the lower alert levels, to part remote/part in-room meetings necessitated the urgent equipping of the rather traditional Cabinet Room in the Beehive with the necessary technology in terms of screens, microphones and speakers. This experience has prompted ongoing work on ensuring that Ministers and officials have access to up-to-date audiovisual equipment in the Beehive.

\section{Proactive release of papers and minutes}

For a number of years now, governments have made it clear that Cabinet material (Cabinet and Cabinet committee papers and minutes) on significant policy decisions should generally be released proactively once decisions have been taken,
The longstanding principles of best practice decision making, as set out in the Cabinet Manual, were
effectively combined with modern technology, the adaptation of systems and processes, and a dash of Kiwi pragmatism, to deliver a decisionmaking approach that supported Ministers to respond to one of the most significant crises New Zealand has ever faced.

most often by publication online. That expectation was promulgated in more detail in October 2018 in Cabinet Office Circular CO(18)4: Proactive Release of Cabinet Material: Updated Requirements. Adherence to the expectations set out in that circular proved challenging during the lockdown. However, with the move to alert level 3, officials and responsible Ministers were once again able to commence the proactive release of Cabinet material. Releases took place on 8 May, 12 May, 26 June, 31 July and 9 October (https:// covid19.govt.nz/updates-and-resources/ legislation-and-key-documents/proactiverelease/\#released-documents-by-category).

\section{Conclusion}

In a Bagehot column in the Economist on 2 May 2020, the author discussed the challenges of governing in a Covid-19 world, and noted: 'The cabinet, cumbersome at the best of times, is ill-designed for crisis' (Bagehot, 2020). New Zealand's experience has been different; our system of executive decision making has proven flexible enough to allow an agile and swift response to a crisis. Ministers were, at incredibly short notice, regularly provided with information, analysis and advice and, in a collective setting, after robust discussion in a virtual environment, made decisions that were accurately and clearly recorded, and quickly promulgated. The longstanding principles of best practice decision making, as set out in the Cabinet Manual, were effectively combined with modern technology, the adaptation of systems and processes, and a dash of Kiwi pragmatism, to deliver a decision-making approach that supported Ministers to respond to one of the most significant crises New Zealand has ever faced. There is now an opportunity to reflect on that experience, to ensure that:

- the back-office technology that supports executive decision making is as effective as it needs to be, in all sorts of different situations; and

- the systems, processes and structures for decision making by Ministers, and the formal processes of making Orders in Council by the Governor-General, continue to be both flexible and robust enough to work effectively in any future crises.

\section{References}

Bagehot (2020) 'Blair's back', Economist, 2

May, p.45

Cabinet Office (2017) Cabinet Manual, Wellington: Cabinet Office 